\title{
PELAKSANAAN STRATEGI PEMBELAJARAN INKUIRI
}

\author{
Maulana Akbar Sanjani \\ Dosen Prodi Administrasi Pendidikan \\ STKIP Budidaya
}

\begin{abstract}
ABSTRAK
Tujuan penulisan ini yaitu membahsan mengenai strategi pelaksanaan pembelajaran inkuiri. Strategi pembelajaran inquiry menyatakan bahwa guru sebagai sumber belajar bukanlah yang satu-satunya, masih banyak lagi sumber belajar yang dapat menunjang keberhasilan pembelajaran. Guru hanyalah sebagai fasilitator, pembimbing yang selalu mengarahkan siswa dalam pembelajaran. Siswa didesain sebagai penemu atau mencari pengetahuan itu, tugas seorang guru dalam mengelola siswa agar mendapatkan pengetahuan dan menjadi bermakna. Karena dengan bermakna pengetahuan akan masuk kedalam pengetahuan mereka, sehingga akan selalu terkenang oleh siswa. Siswa yang melakukan semuanya guru hanya menyiapkan, karena murid yang melakukan maka pembelajaran akan menjadi pengalaman yang bermakna untuk siswa.
\end{abstract}

\section{Kata kunci: Trategi Pembelajaran Inkuiri}

\section{PENDAHULUAN}

Cara guru mengajar menjadi salah satu penentu keberhasilan proses belajar mengajar. Salah satu caranya adalah dengan penerapan model pembelajaran. Model pembelajaran adalah pola yang digunakan sebagai pedoman dalam merencanakan pembelajaran. Model diartikan sebagai kerangka konseptual yang digunakan sebagai pedoman dalam melakukan kegiatan.

Dalam proses pembelajaran yang menggunakan model inkuiri, guru sebagai "fasilitator pembelajaran". Siswa mengajukan beberapa pertanyaan, menimbulkan hipotesis, penelitian dan percobaan, menganalisis data, dan memberikan penjelasan sebagai bukti. Inquiry dibentuk dan meliputi discovery dan lebih banyak lagi. Dengan kata lain, inquiry adalah suatu perluasan proses-proses discovery yang digunakan dalam cara lebih dewasa. Sebagai tambahan pada proses-proses discovery, inquiry mengandung proses-proses mental yang lebih tinggi tingkatannya, misalnya merumuskan problema sendiri, merancang eksperimen, melakukan eksperimen, mengumpulkan dan menganalisis data, menarik kesimpulan, mempunyai sikapsikap obyektif, jujur, hasrat ingin tahu, terbuka, dan sebagainya.

Metode Pembelajaran inquiry merupakan satu komponen penting dalam pendekatan konstruktifistik yang telah memiliki sejarah panjang dalam inovasi atau pembaruan pendidikan. Dalam pembelajaran dengan penemuan atau inkuiri, siswa didorong untuk belajar sebagian besar melalui keterlibatan aktif mereka sendiri dengan konsep-konsep dan prinsip-prinsip, dan guru mendorong siswa untuk memiliki pengalaman dan melakukan percobaan yang memungkinkan mereka menemukan prinsip-prinsip untuk diri mereka sendiri. Piaget memberikan definisi pendekatan Inquiry sebagai pendidikan yang mempersiapkan situasi bagi siswa untuk melakukan eksperimen sendiri. Mengajukan pertayaan-pertayaan dan mencari sendiri 
jawaban atas pertayaan yang mereka ajukan. Metode inkuiri yang didefinisikan sebagai suatu rangkaian kegiatan belajar yang melibatkan secara maksimal seluruh kemampuan siswa untuk mencari dan menyelidiki secara sistematis, kritis, logis, dan analisis sehingga mereka dapat merumuskan sendiri penemuan dengan penuh percaya diri.

\section{KAJIAN TEORETIK}

\section{Pengertian Strategi Pembelajaran Inkuiri}

Sanjaya (2012:196) menerangkan bahwa strategi pembelajaran inkuiri tersebut berangkat dari asumsi bahwa sejak manusia lahir ke dunia, manusia mempunyai dorongan untuk menemukan sendiri pengetahuannya. Rasa ingin tahu tentang keadaan alam disekelilingnya merupakan kodrat manusia sejak lahir ke dunia. Sejak kecil manusia memiliki keinginan untuk mengenal segala sesuatu melalui indera pengecap, pendengaran, pengelihatan, dan indera-indera lainnya. Hingga dewasa keingintahuan manusia secara terus-menerus berkembang dengan menggunakan otak dan pikirannya. Pengetahuan yang dimiliki manusia akan bermakna (mainingfull) manakala didasi oleh keingintahuan itu. Dalam rangka itulah strategi inkuiri dikembangkan. Sagala (2011:196), Metode inkuiri merupakan metode pembelajaran yang berupaya menanamkan dasar-dasar berfikir ilmiah pada diri siswa yang berperan sebagai subjek belajar, sehingga dalam proses pembelajaran ini siswa lebih banyak belajar sendiri, mengembangkan kreativitas dalam memecahkan masalah.

Menurut Piaget dalam Mulyasa (2008) bahwa model pembelajaran inquiry adalah model pembelajaran yang mempersiapkan siswa pada situasi untuk melakukan eksperimen sendiri secara luas agar melihat apa yang terjadi, ingin melakukan sesuatu, mengajukan pertanyaan-pertanyaan, dan mencari jawabannya sendiri, serta menghubungkan penemuan yang satu dengan penemuan yang lain, membandingkan apa yang ditemukannya dengan yang ditemukan siswa lain.

Strategi pembelajaran inkuiri banyak dipengaruhi oleh aliran belajar kognitif. Menurut aliran ini belajar pada hakikatnya adalah proses mental dan proses berpikir dengan memanfaatkan segala potensi yang dimiliki setiap individu secara optimal. Belajar lebih dari sekedar proses menghafal dan menumpuk ilmu pengetahuan, tetapi bagaimana ilmu pengetahuan yang diperolehnya bermakna untuk siswa melalui keterampilan berpikir. Gulo (2002) menyatakan strategi inkuiri berarti suatu rangkaian kegiatan belajar yang melibatkan siswa untuk mencari dan menyelidiki secara sistematis, kritis, logis, analitis, sehingga mereka dapat merumuskan sendiri penemuannya dengan penuh rasa percaya diri. Dapat disimpulkan bahwa metode pembelajaran inkuiri adalah suatu metode pembelajaran yang menekankan siswa dalam memperoleh informasi dengan cara proses berpikir logis dan analitis untuk memecahkan suatu masalah.

\section{Prinsip-prinsip Pembelajaran Inkuiri}

Pembelajaran inkuiri mengacu pada prinsipprinsip berikut ini:

1. Berorientasi pada Pengembangan Intelektual. Tujuan utama dari pembelajaran inkuiri adalah pengembangan kemampuan berpikir. Dengan demikian, pembelajaran ini selain berorientasi kepada hasil belajar juga berorientasi pada proses belajar.

2. Prinsip Interaksi. Proses pembelajaran pada dasarnya adalah proses interaksi, baik interaksi antara siswa maupun 
interaksi siswa dengan guru, bahkan interaksi antara siswa dengan lingkungan. Pembelajaran sebagai proses interaksi berarti menempatkan guru bukan sebagai sumber belajar, tetapi sebagai pengatur lingkungan atau pengatur interaksi itu sendiri.

3. Prinsip Bertanya. Peran guru yang harus dilakukan dalam menggunakan pembelajaran ini adalah guru sebagai penanya. Sebab, kemampuan siswa untuk menjawab setiap pertanyaan pada dasarnya sudah merupakan sebagian dari proses berpikir. Dalam hal ini, kemampuan guru untuk bertanya dalam setiap langkah inkuiri sangat diperlukan. Di samping itu, pada pembelajaran ini juga perlu dikembangkan sikap kritis siswa dengan selalu bertanya dan mempertanyakan berbagai fenomena yang sedang dipelajarinya.

4. Prinsip Belajar untuk Berpikir. Belajar bukan hanya mengingat sejumlah fakta, akan tetapi belajar adalah proses berpikir (learning how to think), yakni proses mengembangkan potensi seluruh otak. Pembelajaran berpikir adalah pemanfaatan dan penggunaan otak secara maksimal.

5. Prinsip Keterbukaan. Pembelajaran yang bermakna adalah pembelajaran yang menyediakan berbagai kemungkinan sebagai hipotesis yang harus dibuktikan kebenarannya. Tugas guru adalah menyediakan ruang untuk memberikan kesempatan kepada siswa mengembangkan hipotesis dan secara terbuka membuktikan kebenaran hipotesis yang diajukannya.

\section{PEMBAHASAN}

Pembelajaran inkuiri menekankan kepada proses mencari dan menemukan. Materi pelajaran tidak diberikan secara langsung. Peran siswa dalam pembelajaran ini adalah mencari dan menemukan sendiri materi pelajaran, sedangkan guru berperan sebagai fasilitator dan pembimbing siswa untuk belajar. Pembelajaran inkuiri merupakan rangkaian kegiatan pembelajaran yang menekankan pada proses berpikir kritis dan analitis untuk mencari dan menemukan sendiri jawaban dari suatu masalah yang dipertanyakan. Proses berpikir itu sendiri biasanya dilakukan melalui tanya jawab antara guru dan siswa. Pembelajaran ini sering juga dinamakan pembelajaran heuristic, yang berasal dari bahasa Yunani, yaitu heuriskein yang berarti "saya menemukan".

Secara umum Sanjaya (2012: 199) mengemukakan bahwa proses pembelajaran dengan mengguanakan strategi pembelajaran inkuiri dapat mengikuti langkah-langkah sebagai berikut:

1. Orientasi

Langkah orientasi adalah langkah untuk membina suasana atau iklim pembelajaran yang responsive. Pada langkah ini guru mengondisikan agar siswa siap melaksanakan proses pembelajaran. Berbeda dengan tahapan preparation dalam strategi pembelajaran ekspositori (SPE) sebagai langkah untuk mengkondisikan agar siswa tiap menerima pelajaran, pada langkah orientasi dalam SPI, guru merangsang dan mengajak siswa untuk berpikir memecahkan masalah. Langkan orientasi merupakan langkah yang sangat penting. Keberhasilan stratgi pembelajaran inkuiri sangat tergantung pada kemauan siswa untuk beraktivitas menggunakan kemampuannya dalam memecahkan masalah; tanpa kemauan dan kemampuan itu tak 
mungkin proses pembelajaran akan berjalan dengan lancar. Beberapa hal yang dapat dilakukan dalam tahapan orientasi ini adalah

a) Menjelaskan topik, tujuan, dan hasil belajar yang diharapkan dapat dicapai oleh siswa.

b) Menjelaskan pokok-pokok kegiatan yang harus dilakuakn oleh siswa untuk mencapai tujuan. Pada tahap ini dijelaskan langkah-langkah inkuiri serta tujuan setiap langkah, mulai dari langkah merumuskan masalah sampai dengan merumuskan kesimpulan.

c) Menjelaskan pentingnya topik dan kegiatan belajar. Hal ini dilakukan dalam rangka memberikan motivasi belajar siswa.

\section{Merumuskan Masalah}

Merumuskan masalah merupakan langkah membawa siswa pada suatu persoalan yang mengandung teka-teki. Persoalan yang disajikan adalah persoalan yang menantang siswa untuk berpikir memecahkan teka teki itu. Dikatakan teka teki dalam rumusan masalah yang ingin dikaji disebabkan masalah itu tentu ada jawabannya dan siswa didorong untuk mencari jawaban yang tepat. Proses mencari jawaban itulah yang sangat penting dalam strategi inkuiri, oleh sebab itu melalui proses tersebut siswa akan memperoleh pengalaman yang sangat berharga sebagai upaya mengembangkan mental melalui proses berpikir. Dengan demikian, teka teki yang menjadi masalah dalam berinkuiri adalah teka teki yang mengandung konsep yang jelas yang harus dicari dan ditemukan. Ini penting dalam pembelajaran inkuiri. Beberapa hal yang harus diperhatiakan dalam merumuskan masalah, diantaranya:

a) Masalah hendaknya dirumusakn sendiri oleh siswa. Siswa akan memiliki motivasi belajar yang tinggi manakala dilibatkan dalam merumuskan masalah yang hendak dikaji. Dengan demikian, guru sebaiknya tidak merumuskan sendiri masalah pembelajaran, guru hanya memberikan topik yang akan dipelajari, sedangkan bagaimana rumusan masalah yang sesuai dengan topik yang telah ditentukan sebaiknya diserahkan kepada siswa.

b) Masalah yang dikaji adalah masalah yang mengandung teka teki yang jawabannya pasti. Artinya guru dapat mendorong agar siswa dapat merumuskan masalah yang menurut guru jawaban sebenarnya sudah ada, tinggal siswa mencari dan mendapatkan jawabannya secara pasti.

c) Konsep-konsep dalam masalah adalah konsep-konsep yang sudah diketahui terlebih dahulu oleh siswa. Artinya sebelum masalah itu dikaji lebih jauh melalui proses inkuiri, guru perlu yakin terlebih dahulu bahwa siswa sudah memiliki pemahaman tentang konsepkonsep yang ada dalam rumusan masalah. Jangan harapkan siswa dapat melakukan tahapan inkuiri selanjutnya, manakalaia belum paham konsepkonsep yang terkandung dalam rumusan masalah.

\section{Merumuskan Hipotesis}

Hipotesis adalah jawaban sementara dari suatu permasalahan yang sedang dikaji. Sebagai jawaban sementara, hipotesis perlu diuji kebenarannya. Kemampuan atau potensi individu untuk berpikir pada dasarnya sudah dimiliki sejak individu itu lahir. Potensi berpikir itu dimulai dari kemampuan setiap individu untuk menebak atau mengira-ngira (berhipotesis) dari suatu permasalahan. 
Manakala individu dapat membuktikan tebakannya, maka ia akan sampai pada posisi yang bisa mendorong untuk berpikir lebih lanjut. Oleh sebab itu, potensi untuk mengembangkan kemampuan menebak pada setiap individu harus dibina. Salah satu cara yang dapat dilakukan guru untuk mengembangkan kemampuan menebak (berhipotesis) pada setiap anak adalah dengan mengajukan berbagai pertanyaan yang dapat mendorong siswa untuk dapat merumuskan jawaban sementara atau dapat merumuskan berbagai perkiraan kemungkinan jawaban dari suatu permasalahan yang dikaji. Perkiraan sebagai hipotesis bukan sembarang perkiraan, tetapi harus memiliki landasan berpikir yang kokoh, sehingga hipotesis yang dimunculkan itu bersifat rasional dan logis. Kemampuan berpikir logis itu sendiri akan sangat berpengaruh oleh kedalaman wawasan yang dimiliki serta keluasan pengalaman. Dengan demikian, setiap individu yang kurang mempunyai wawasan akan sulit mengembangkan hipotesis yang rasional dan logis.

4. Mengumpulkan Data

Mengumpulkan data adalah aktivitas menjaring informasi yang dibutuhkan untuk menguji hipotesis yang diajukan. Dalam strategi pembelajaran inkuiri, mengumpulkan data merupakan proses mental yang sangat penting dalam pengembangan intelektal. Proses pengumpulan data bukan hanya memerlukan motivasi yang kuat dalam belajar, akan tetapi juga membutuhkan ketekunan dan kemampuan menggunakan potensi berpikirnya. Oleh sebab itu, tugas dan peran gutu dalam tahapan ini adalah mengajukan pertanyaan-pertanyaan yang dapat mendorong siswa untuk berpikir mencari informasi yang dibutuhkan. Sering terjadi kemacetan berinkuiri adalah manakal siswa tidak apresiatif terhadap pokok permasalahan. Tidak apresiatif itu biasanya ditunjukkan oleh gejala-gejala ketidakbergairahan dalam belajar. Manakala guru menemukan gejala-gejala semacam ini, maka guru hendaknya secara terus menerus memberikan dorongan kepada siswa untuk belajar melalui penyuguhan berbagai jenis pertanyaan secara merata kepada seluruh siswa sehingga meraka terangsang untuk berpikir.

5. Menguji Hipotesis

Menguji hipotesis adalah proses menentukan jawaban yang dianggap diterima sesuai dengan data dan informasi yang diperoleh berdasarkan pengumpulan data. Yang terpenting dalam menguji hipotesis adalah mencari tingkat keyakinan siswa atau jawaban yang diberikan. Disamping itu, menguji hipotesis juga berarti mengembangkan kemampuan berikir rasional. Artinya, kebenaran jawaban yang diberikan bukan hanya berdasarkan argumentasi, akan tetapi harus didukung oleh data yang ditemukan dan dapat dipertanggung jawabkan.

6. Merumuskan Kesimpulan

Merumuskan kesimpulan adalah proses mendeskripsikan temuan yang diperoleh berdasarkan hasil pengujian hipotesis. Merumukan kesimpulan merupakan gong-nya dalam proses pembelajaran. Sering terjadi, oleh karena banyaknya data yang diperoleh, menyebabkan kesimpulan yang dirumuskan tidak focus terhadap masalah yang hendak dipecahkan. Karena itu, untuk mencapai kesimpulan yang akurat sebaiknya guru mampu menunjukkan pada siswa data mana yang relevan.

\section{KESIMPULAN}

$\begin{array}{ccc}\text { Strategi pembelajaran } & \text { inquiry } \\ \text { menyatakan bahwa guru sebagai } & \text { sumber }\end{array}$ 
belajar bukanlah yang satu-satunya, masih banyak lagi sumber belajar yang dapat menunjang keberhasilan pembelajaran. Guru hanyalah sebagai fasilitator, pembimbing yang selalu mengarahkan siswa dalam pembelajaran.

Siswa didesain sebagai penemu atau mencari pengetahuan itu, tugas seorang guru dalam mengelola siswa agar mendapatkan pengetahuan dan menjadi bermakna. Karena dengan bermakna pengetahuan akan masuk kedalam pengetahuan mereka, sehingga akan selalu terkenang oleh siswa. Siswa yang melakukan semuanya guru hanya menyiapkan, karena murid yang melakukan maka pembelajaran akan menjadi pengalaman yang bermakna untuk siswa.

\section{DAFTAR PUSTAKA}

Gulo, W. (2002). Strategi Belajar-Mengajar. Jakarta: PT. Gramedia.

Mulyasa, E. (2008). Menjadi Guru Profesional, Menciptakan Pembelajaran Kreatif dan Menyenangkan. Bandung: Remaja Rosdakarya.

Sagala, S. (2011). Konsep dan Makna Pembelajaran. Bandung: Alfabeta.

Sanjaya, W. (2012). Strategi Pembelajaran Berorientasi Standar Proses Pendidikan. Jakarta: Kencana. 